PRZEGLĄD BIBLIOTECZNY 2019 z. 2

PL ISSN 0033-202X

WERONIKA KORTAS

Uniwersytet Mikołaja Kopernika w Toruniu e-mail: wkortas@doktorant.umk.pl

\title{
CZŁONKOWIE POLSKICH GRUP W SERWISIE FACEBOOK A ZJAWISKO CZYTANIA SPOŁECZNOŚCIOWEGO ${ }^{1}$
}

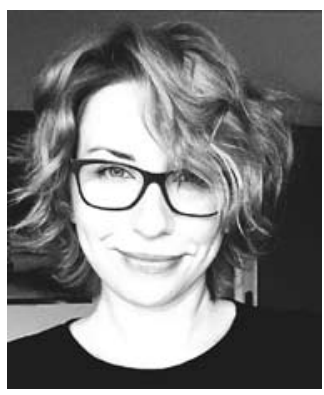

Weronika Kortas, mgr, uczestniczka studiów doktoranckich z zakresu bibliologii i informatologii na Uniwersytecie Mikołaja Kopernika w Toruniu; absolwentka bibliotekoznawstwa i informacji naukowej oraz socjologii na UMK. Jej zainteresowania naukowe koncentrują się na społecznościach internetowych - ich funkcjonowaniu, komunikacji wewnętrznej i zewnętrznej oraz zaspokajaniu potrzeb informacyjnych przez ich członków, a także na user centered design, user experience oraz social reading. Założycielka i przewodnicząca Koła Naukowego Doktorantów „Pytanie”, organizatorka kilku konferencji naukowych, w tym I Ogólnopolskiej Konferencji Naukowej WIAD19 (w ramach ogólnoświatowego Dnia Architektury Informacji), członek Międzynarodowego Towarzystwa Naukowego ISKO, redaktorka czasopisma naukowego „Toruńskie Studia Bibliologiczne”.

SŁOWA KLUCZOWE: Czytanie społecznościowe. Czytelnictwo. Facebook. Grupy na Facebooku. Książki. Social reading.

ABSTRAKT: Tezy/cel artykułu - social reading (czytanie społecznościowe) jest zjawiskiem angażującym większe grupy ludzi w czytanie danego tekstu. Technologia w sposób naturalny jest aktywatorem tego typu działań. Celem artykułu jest próba analizy wyników badania ankietowego sprawdzającego, czy członkowie wybranych polskich grup na

\footnotetext{
${ }^{1}$ Badania przeprowadzono w ramach grantu WNH UMK nr 1137-NH: Analiza sposobów popularyzacji czytelnictwa w serwisie Facebook.
} 
Facebooku wiedza, na czym polega zjawisko social reading, czy brali w nim udział - świadomie lub nie - oraz czy są takim udziałem zainteresowani. Metody badań - założono, że wybrane zostaną dwie polskie grupy związane z książkami i dwie o tematyce ogólnej, których nazwy i opisy nie wskazują na powiązanie z czytelnictwem. Grupy wybrane zostały losowo spośród tych, które mają minimum 5 tys. członków i opublikowano w nich co najmniej 500 postów w ciągu ostatnich 30 dni. Jeśli chodzi o tematykę, to wykluczone zostały grupy dotyczące konkretnego zagadnienia. $W$ wyniku przeprowadzonej selekcji o wypełnienie kwestionariusza poproszeni zostali członkowie następujących grup: „Kreatywne dziewczyny od Ani”, „Wrocław - sorry, że nie w temacie”, ,Książki - sprzedażl wymiana książek”, ,Nie mam czasu, czytam książki”. W sumie kwestionariusz wypełniło 1000 respondentów. Wyniki i wnioski - z analizy odpowiedzi wynika, że mniej niż połowa respondentów rozumie pojęcie social reading, a 34,8\% osób przyznało się do udziału $\mathrm{w}$ jakiejś formie dyskusji online na temat książki, np. na forum internetowym, w grupie na Facebooku, w sekcji komentarzy pod postami dotyczącymi danej publikacji, itd.

\section{WPROWADZENIE}

Celem artykułu jest próba analizy wyników badania ankietowego, sprawdzającego, czy członkowie wybranych polskich grup na Facebooku wiedza, czym jest zjawisko social reading (czyli czytanie i dzielenie się swoimi przemyśleniami z innymi) oraz czy brali w nim udział - celowo lub nieświadomie. Ponadto próbowano również ustalić chęć respondentów do zaangażowania się w czytanie w sposób społecznościowy.

Na początek wyjaśnionych zostanie kilka kluczowych, dla tematu, pojęć. W artykule "Pole semantyczne terminu «książka elektroniczna»" Jarosław Pacek tłumaczy, że „,z zestawienia kategorii cech książki elektronicznej wynika, że najważniejszą cechą różnicująca, wskazywaną przez twórców definicji, jest specyficzny sposób odczytu książki elektronicznej, który wymaga zastosowania urządzenia elektronicznego. To właśnie stanowi jądro znaczenia terminu książka elektroniczna" (Pacek, 2016).

Termin publikacja online rozumiany jest jako dokument elektroniczny wykorzystujący techniki multimedialne i/lub hipertekstowe. Do jego odczytu potrzebne jest pośredniczące urządzenie elektroniczne, np. komputer, tablet, czytnik ebooków, itp.

„Na podstawie analizy tekstu Boba Steina pt. Taxonomy of Social Reading. A Proposal ${ }^{2}$ oraz artykułu Allison Mennelli, pt. Social Reading and Libraries, wyróżnić można pięć typów social reading. Są to: tradycyjne rozmowy na temat książek; tradycyjne kluby książki, rozmowy na lekcji itd.; kluby książki online; media społecznościowe poświęcone książkom oraz czytanie online «na dynamicznym marginesie książki»" (Kortas, 2018).

${ }^{2}$ B. Stein, A Taxonomy of Social Reading. A Proposal [online] [dostęp 20 kwietnia 2018]. Dostępny w WWW: http://futureofthebook.org/social-reading/. 
W badaniu opisywanym $\mathrm{w}$ niniejszym tekście skupiono się na czytaniu, które odbywa się na portalu społecznościowym Facebook. W związ$\mathrm{ku} \mathrm{z}$ tym pokrótce zdefiniowane zostaną tylko typy: kluby książki online, media społecznościowe poświęcone książkom, czytanie online „na marginesach książki"3.

„Kluby książki online” to miejsca, które zostały stworzone specjalnie po to, by móc w nich rozmawiać na temat czytanych lub przeczytanych tekstów. Istnieją zarówno kluby ogólne, jak i poświęcone konkretnemu autorowi, epoce, rodzajowi literatury itd. Członkowie mogą zabierać głos w dyskusji niezależnie od tego, gdzie są i która jest u nich godzina (What is a book club?).

Media społecznościowe poświęcone książkom to miejsca, w których (zazwyczaj) po rejestracji i założeniu konta, użytkownicy mogą oceniać, komentować, polecać, katalogować, szukać, tworzyć różnego rodzaju listy, np. książek przeczytanych itd. Media społecznościowe dały masowemu odbiorcy możliwość włączenia się do grona dyskutujących o książkach. Mowa tu m.in. o stronach WWW jak Goodreads, Amazon, Shelfari czy polskie BiblioNetka, LubimyCzytać.pl itd. Pomocne są również takie narzędzia jak Reddit, Digg czy Delicious, które pozwalają na gromadzenie, kategoryzację i dzielenie się zakładkami.

Czytanie online „na marginesach książki” polega na korzystaniu z możliwości komentowania każdej przeczytanej strony lub akapitu. W tym celu wykorzystuje się takie narzędzia jak Comment Press, Digress It czy Book Glutton. Dzięki nim, każda ze stron tekstu wyposażona zostaje w dynamiczny margines umożliwiający wymianę myśli między czytelnikami na temat fragmentu, który ich zainteresował (Kortas, 2017).

Rewolucja internetowa wywołała gwałtowny wzrost czytania i pisania online, a co za tym idzie - nową terminologię. Wśród terminów, które miałyby nazywać nowo powstałe zjawisko, pojawiały się m.in.: „wreading” („czytanie jako akt pisania”), "czytanie online”, "czytanie interaktywne”, "czytanie współdzielone” czy w końcu „social reading” (Cordón-García, 2013).

Mary K. Tod w artykule Social media \& social reading - an author's view zauważa, że zjawisko social reading staje się czymś wszechobecnym poprzez Internet i urządzenia mobilne. Na pytanie zadane w ankiecie z 2015 r., przeprowadzonej na ponad 2 tys. czytelników, które brzmiało: „proszę ocenić swój stosunek do poniższych stwierdzeń dotyczących mediów społecznościowych i czytania”, 45\% respondentów przyznało, że "pod wpływem mediów społecznościowych czyta więcej niż dotychczas" (Tod, 2015).

${ }^{3}$ Szersze objaśnienia znaleźć można w artykule Social Reading w kontekście nowych technologii: historia, rodzaje, projekty. Toruńskie Studia Bibliologiczne, nr 2 (19), 2017, [online], [dostęp: 10.03.2018], <http://apcz.umk.pl/czasopisma/index.php/TSB/article/view/TSB.2017.024/14186>. 
„W czytaniu społecznościowym chodzi o związki: czytelników z pisarzami, czytelników z czytelnikami, czytelników z recenzentami i blogerami, pisarzy z pisarzami i blogerów z blogerami [...]. Takie relacje są osobiste, angażujące czas i wysiłek tych, którzy się angażują" (Tod, 2014). W badaniu ankietowym z 2013 r., w którym przebadano ponad 2400 osób, 1473 respondentów wymieniło jedną lub kilka stron czytelniczych. Czytanie społecznościowe umożliwia współdzielenie doświadczania czytanej książki. Niektórzy czytelnicy wolą dołączyć do fizycznie istniejących klubów książki, inni wybierają kluby książki online.

W dalszej części artykułu Tod wyjaśnia, że w ankiecie przeprowadzonej w 2015 r. (Tod, 2015) poproszono respondentów, by odnieśli się do określonych stwierdzeń. Najwięcej osób zgodziło się z takimi odpowiedziami jak: „media społecznościowe pozwalają mi wypowiedzieć się na temat książek, które przeczytałem”, "media społecznościowe sprawiaja że łatwiej jest mi znaleźć książki, które lubię" i „lubię poczucie wspólnoty mediów społecznościowych umożliwiających czytanie". 50\% osób stwierdziło, że "media społecznościowe zmieniły sposób w jaki czytam” (Tod, 2015). Ponadto autorka zauważa, że czytelnicy oczekują od autorów zaangażowania $w$ społeczność oraz tego, żeby to zaangażowanie z obu stron miało wymiar osobisty. Poza tym „publiczność zwiększa publiczność" (Tod, 2014). Stwierdzenie to oznacza, że czytelnicy poprzez polecanie sobie kolejnych książek, komentowanie, zapraszanie znajomych itd. wpływają na rozrastanie się społeczności czytelniczej. Tod w raporcie podkreśla, że to czytelnicy z USA i Australii najbardziej cenią sobie użycie mediów społecznościowych w trakcie czytania (Tod, 2014).

Ważną postacią $\mathrm{w}$ historii social reading jest Bob Stein. Jego nietradycyjne podejście do czytelnictwa sięga czasów, gdy studiował w Massachusetts Institute of Technology. W 1979 r. zajmował się tam projektem interaktywnego czytania. Stein stworzył określenie social book (książka społecznościowa) w odniesieniu do publikacji, która umożliwia wymianę informacji, współpracę między czytelnikami, autorami, komentowanie i integrację w różnego rodzaju sieciach (Cordón-García, 2013). Według Steina „czytanie i pisanie zawsze były czynnościami społecznościowymi, ale fakt ten przysłaniało medium, jakim jest druk" (Moyer, 2009). Po kilku latach prób nadążenia w swojej działalności za technologia, Stein skupił się na tzw. networked book (książce sieciowej), czyli „podłączonej” do Internetu i „łączącej” z podobnie myślącymi czytelnikami (Moyer, 2009).

„Dla Steina, social oznacza prowadzenie dyskusji na marginesach książki. Gdy czytamy społecznie, tworzymy w książce różnego rodzaju graficzne oznaczenia. Social oznacza również dostęp do komentarzy wszystkich czytelników z danego systemu oraz możliwość zaangażowania się w kontakt $\mathrm{z}$ autorami. Kontakt w książce następuje w sposób niesynchronicz- 
ny ${ }^{4}$ lub w czasie rzeczywistym". (Cordón-García, 2013) Zdaniem Steina doświadczenie czytania daje czytelnikowi dostęp do nowego wymiaru, tak jak komentowanie łączy czytanie i pisanie nakłaniając do głębszych rozważań nad tekstem (Cordón-García, 2013).

Allison Mennella podkreśla, żeby można było mówić o zjawisku społecznego czytania, „potrzebna jest interakcja pomiędzy tekstem a co najmniej dwoma jego czytelnikami. Kluczowym elementem jest tutaj wartość dodana do tekstu przez poszczególne osoby: komentarze, przemyślenia, notatki na marginesach itd. Czytelnik musi chcieć przekazać swoje zdanie innym. Może tego dokonać np. poprzez napisanie recenzji" (Kortas, 2018). A. Mennella, opierajac się na artykule The Meaning of Social Reading and Where It's Headed, tłumaczy, że „ludzie chcą dzielić się z innymi ludźmi tym, co przeczytali oraz otrzymywać informacje zwrotne na temat swoich przemyśleń i pomysłów. Technologia jest do tego doskonałym oraz naturalnym narzędziem" (Mennella, 2011). Autorka powołuje się również na myśl Tylera Shoresa, że „czytanie książki nie powinno być doświadczeniem pasywnym, ale raczej hałaśliwą konwersacją" (Shores, 2011).

Umberto Eco w książce Dzieło otwarte. Forma i nieokreśloność w poetykach współczesnych wyjaśniał, że dzieła sztuki są tworami otwartymi. Autor wspomnianą otwartość definiował jako „propozycję możliwości interpretacyjnych, układ bodźców, których zasadniczą cechą jest ich nieokreśloność, sprawiająca, że odbiorca zmuszony jest do całej serii nieustannie zmieniających się odczytań" ${ }^{5}$ (Eco, 1972).

Czytanie społecznościowe jako „czytanie w środowisku wirtualnym, gdzie książka i czytanie sprzyjają formowaniu się społeczności i miejsca wymiany" zdefiniowano w książce Social Reading: Platforms, Applications, Clouds and Tags z 2013 r. (Cordón-García, 2013). Coraz ważniejsze stają się strony oparte na standardach Web 2.0, oferujące czytanie współdzielone za pośrednictwem sieci. Autorzy zauważyli, że „bezpośrednio doświadczamy rewolucji, która, w odróżnieniu od tej związanej z wynalezieniem prasy drukarskiej, zawiera $\mathrm{w}$ sobie wiele małych rewolucji, które następują po sobie z dnia na dzień, mikrorewolucję techniki, która zmienia się w tym samym czasie, co systemy czytania i pisania, percepcji i związanych praktyk. [...] Jednym z tych trendów jest socjalizacja czytania z serią technologicznych, instytucjonalnych, akademickich i profesjonalnych propozycji, które zachęcają do współpracy i wymiany. Czytanie staje się coraz bardziej społecznościowe, aczkolwiek to zawsze była jego cecha charakterystyczna" (Cordón-García, 2013).

Jeśli chodzi o teksty polskie na temat social reading, to warto wspomnieć raport pt. Jak czytaja Polacy? Raport badawczy projektu "Zmiany kultury czy-

\footnotetext{
${ }^{4}$ Niesynchroniczny oznacza, że rozmówcy prowadzą rozmowę pisząc do siebie kolejne odpowiedzi po upływie jakiegoś czasu, np. godziny, na drugi dzień itd.

${ }^{5}$ U. Eco: Dzieło otwarte. Forma i nieokreśloność w poetykach wspótczesnych. Warszawa 1972, s. 159.
} 
telniczej w Polsce w kontekście upowszechnienia e-tekstów i urządzeń pozwalajacych z nich korzystać" z 2016 r. Społecznościowemu czytaniu poświęcono tu jeden podrozdział, a samo zjawisko zdefiniowano jako „wprowadzanie i korzystanie $\mathrm{z}$ aplikacji umożliwiających aktywność $\mathrm{w}$ mediach społecznościowych lub analogiczne działania w obrębie książki (komentowanie, obserwowanie itp.)" (Kisilowska, 2016).

Inną polską publikacją jest książka Macieja Maryla, pt. _życie literackie $w$ sieci: pisarze, instytucje i odbiorcy wobec przemian technologicznych. Autor co prawda nie odnosi się tu bezpośrednio do czytania społecznościowego, jednak m.in. $\mathrm{w}$ rozdziale XI, pt. Czytanie romansu online: kolektywny odbiór literatury $w$ internecie, porusza zagadnienia z nim związane. Maryl wyjaśnia m.in., że „jak pokazują antropologiczne badania wspólnot czytelniczych, kolektywna lektura polega na wspólnym wypracowaniu stanowiska wobec utworu i odczytaniu go przez pryzmat indywidualnego bądź grupowego doświadczenia. Przekonują o tym chociażby badania czytelnicze romansów przeprowadzone przez Janice Radway czy wnioski Elizabeth Long z obserwacji uczestniczących w dyskusyjnych klubach książki w Houston. W obydwu pracach nacisk położony jest na kolektywne aspekty lektury - autorki stoją na stanowisku, iż jest ona zjawiskiem społecznym" (Maryl, 2015, s. 323).

Autor wyjaśnia również, że m.in. fora, portale poświęcone książkom, serwisy społecznościowe czy blogi są miejscami, w których powstają wspólnoty lekturowe online. Wspomina również croudsourcing, „czyli wykorzystanie wiedzy zbiorowej innych użytkowników" (Maryl, 2015, s. 332), np. w przypadku rekomendowania książek - zarówno przez innych, jak i za pomocą algorytmów (Maryl, 2015, s. 332).

W swojej pracy Maryl podjął się m.in. analizy forum „Romance”, które umiejscowione jest na portalu Amazon.com. Na podstawie badań stwierdził, że „mamy do czynienia ze swoistą personalizacją wyborów lekturowych. Czytelnicy poszukują książek odpowiadających ich oczekiwaniom, przykrawając ofertę do własnych potrzeb. (...) Więcej światła na ten aspekt rzuca sposób prowadzenia dyskusji o książkach. (...) Istotny jest tu nie tyle konsensus czy przekonanie kogoś do swoich racji, ile (...) wielogłosowość i poszanowanie odmiennych punktów widzenia. Użytkownicy mogą jednak głosować nad tym, czy dany wpis wnosi coś do dyskusji (...). Dyskusje na forum pozwalają zatem na prezentację własnego zdania (...)" (Maryl, 2015, s. 339). Za pośrednictwem Internetu przedstawiciele różnych kultur mogą znaleźć osoby myślące podobnie, a dyskusja na temat danego tekstu jest pretekstem do nawiązania relacji z innymi. „Warto tu jednak podkreślić, że nieinternetowe grupy czytelnicze pełnią podobne funkcje: tekst staje się pretekstem do spotkania i interakcji, w której poszerza się zakres doświadczenia jednostki" (Maryl, 2015, s. 341-342). 


\section{METODOLOGIA BADAŃ}

W badaniu podjęto próbę zebrania informacji o tym, czy internauci należący do wybranych polskich grup na Facebooku wiedza, czym jest czytanie społecznościowe, czy brali w nim udział (świadomie lub nieświadomie) i czy są taką formą dyskusji o książkach zainteresowani. Badanie przeprowadzone zostało w listopadzie 2017 r. w ramach grantu Wydziału Nauk Historycznych UMK, 2920-NH, pt. Analiza sposobów popularyzacji czytelnictwa w serwisie Facebook. Cztery pytania dotyczące czytania społecznościowego znajdowały się w sekcji nr 12, będącej częścią bardziej złożonego kwestionariusza, pt. Czytelnicy w mediach społecznościowych. Ankieta stworzona została za pomocą narzędzia „Formularze Google”.

Jeśli chodzi o dobór próby, to założono, że wybrane zostaną dwie polskie grupy związane z książkami i dwie o tematyce ogólnej, których nazwy i opisy nie wskazują na powiązanie z czytelnictwem. Grupy wybrano losowo spośród tych, które mają minimum 5 tys. członków i opublikowano w nich co najmniej 500 postów w ciągu ostatnich 30 dni. Wykluczone zostały grupy związane ściśle z konkretnym tematem, m.in.: z chorobami/ stanem zdrowia, dieta/żywieniem, motoryzacją rękodziełem, podróżami, dotyczące zwierząt, wychowania itd.

W wyniku przeprowadzonej selekcji o wypełnienie ankiety poproszeni zostali członkowie następujących grup: „Kreatywne dziewczyny od Ani” (ok. 6500 członków i 800 postów) ${ }^{6}$, "Wrocław - sorry że nie w temacie" (ok. 90 tys.; 10 tys. postów) ${ }^{7}$, „Książki - sprzedaż/wymiana książek” (ok. 67 tys.; 5800 postów) ${ }^{8}$, „Nie mam czasu, czytam książki” (ok. 56 tys.; 1500 postów $)^{9}$.

W sumie kwestionariusz wypełniło 1000 respondentów. Wszystkie ankiety zostały uzupełnione poprawnie. $87,3 \%$ respondentów stanowią kobiety (873), a największe grupy wiekowe to $19-25$ (35,9\%) i $26-35$ (30,2\%).

Wysyłanie ankiet odbywało się etapami. Polegało to na tym, że po zebraniu zadowalającej liczby wypełnionych kwestionariuszy w jednej grupie, link był kasowany, a prośbę publikowano w kolejnej grupie. Dzięki temu, liczba respondentów z poszczególnych grup jest podobnej wielkości.

\section{WYNIKI BADANIA}

96,7\% przebadanych osób zgodziło się ze stwierdzeniem „lubię czytać książki". Zaledwie 33 osoby odpowiedziały na to pytanie przecząco. Według raportu dotyczącego stanu czytelnictwa w Polsce przygotowanego

\footnotetext{
${ }^{6} 3655$ członków - stan na 19.05.2019.

${ }^{7} 201812$ członków - stan na 19.05.2019.

887447 członków - stan na 19.05.2019.

${ }^{9} 61322$ członków - stan na 19.05.2019.
} 
przez Bibliotekę Narodową przynajmniej jedną książkę w 2017 r. przeczytało 38\% osób. Jest to o jeden punkt procentowy więcej niż w latach 2015-2016. 9\% Polaków sięga po co najmniej siedem książek w ciągu roku. $\mathrm{Z}$ badania wynika, że osoby należące do tej grupy wpływają mobilizująco na swoje najbliższe otoczenie. „Analiza związku otoczenia z praktyką lekturową wykazała dobitnie, że osoby z domów, gdzie czytają wszyscy pozostali, same także czytają książki (aż 82\%), w przeciwieństwie do domów, w których się nie czyta (tu tylko 13\% deklarowało czytanie). Jeszcze wyraźniej widać tę zależność w pytaniu o znajomych i przyjaciół: w nieczytającym kręgu towarzyskim znajdziemy zaledwie 5\% czytelników" (38\% Polaków..., 2017). Na podstawie tych danych stwierdzić można, że czytanie jest zjawiskiem społecznościowym.

Jeśli chodzi o źródła, z jakich ludzie czerpią informacje, to 37\% osób, które deklarują się jako czytelnicy książek, „czerpią wiadomości o świecie także za pośrednictwem lektury, często online (...), podczas gdy nieczytający wybierają przede wszystkim radio i telewizję (55\%)" (38\% Polaków..., 2017). Badanie przeprowadzono na ogólnopolskiej próbie reprezentatywnej-3185 respondentów, którzy mieli co najmniej 15 lat (38\% Polaków..., 2017).

Być może czytelnikowi nasuwa się w tym miejscu pytanie, dlaczego wg wspomnianego raportu, w 2017 r. przynamniej jedną książkę przeczytało 38\% badanych? (38\% Polaków..., 2017). Warto jednak zwrócić uwagę na fakt, że w ankiecie pytano o to, czy respondenci lubią czytać, a nie o to, czy czytają.

Poza tym z szybkości wypełniania ankiet (1000 uzupełnionych kwestionariuszy uzyskano już po 2 dniach), reakcji na prośbę o wypełnienie kwestionariusza (entuzjastyczna), a także na zamknięcie kwestionariusza (irytacja, złość), wynika, że osoby czytające chętne są do opowiadania o swoich doświadczeniach czytelniczych. Jest więc bardzo prawdopodobne, że tytuł ankiety Czytelnicy w mediach społecznościowych "przyciągnął” osoby, które uważają się za czytelników. W sumie link do ankiety kliknięty został 4623 razy (stan na 27.11.2017 r.). Źródłem wspomnianej informacji statystycznej jest strona Google URL Shortener (https:/goo.gl/), która została użyta do skrócenia linku prowadzącego do ankiety. Zalogowany użytkownik, który ze strony skorzystał, ma dostęp do informacji o tym, ile razy dany link został kliknięty.

Jeżeli chodzi o przedmiot tej części projektu badawczego, to 590 (59\%) osób stwierdziło, że nie wie, co oznacza pojęcie social reading. Na pytanie „Czy kiedykolwiek brał/a Pan/i udział w dyskusji online (w Internecie) na temat książki?"“ zaledwie 348 (34,8\%) respondentów odpowiedziało twierdząco.

W kolejnym pytaniu osoby, które odpowiedziały „tak”, proszone były o podzielenie się informacjami na ten temat. Z odpowiedzi, których udzieliło 239 osób (23,9\%) wynika, że większość z nich brała udział w jakiejś 
formie wymiany zdań na temat książek, w grupach na Facebooku. Respondenci informowali m.in. o podjęciu dyskusji na temat powieści „Małe życie”, „Thorn”, trylogii „Millenium” lub „najlepszych powieści fantastyki". Inni pisali recenzje książek, np. Janusza Leona Wiśniewskiego, Cassandry Clare, czy Joanne Kathleen Rowling. Część z respondentów przyznała, że udziela się w grupach na Facebooku rzadko, poprzez sporadyczne polecenie jakiegoś tytułu lub przyznanie się do przeczytania danej książki.

Z odpowiedzi udzielonych przez respondentów wynika, że równie często, co na Facebooku, biorą oni udział w komentowaniu, dyskusjach itd. na temat książek na innych portalach. Najczęściej wymieniane były takie strony jak BiblioNetka i Lubimy Czytać. Obrazują to przykładowe komentarze: „Na LubimyCzytać.pl, w komentarzach pod recenzjami książek“, "Na lubimyczytać.pl udzielałam się wielokrotnie, głównie pod publikacjami fantasy oraz branżowymi związanymi z dietetyką, ponieważ takie studia ukończyłam wcześniej“, „Recenzja na LubimyCzytać.pl“, „Na lubimyczytac.pl pisałem z ludźmi o książkach, które przeczytałem.", „W serwisie BiblioNETka zdarza mi się sporadycznie dodać komentarz do jakiejś książki“. Dużo rzadziej wymieniony został portal akademia.edu czy serwisy Instagram i YouTube. Ponadto część z respondentów wymieniła blogi.

Z odpowiedzi respondentów wynika, że często biorą oni udział w wymianie zdań w komentarzach pod poszczególnymi postami. Częstotliwość takich działań jest różna - od pojedynczych komentarzy do częstszych dyskusji. Jako przykłady tematów, których dotyczyły dyskusje, można tu podać: "Sekrety Twin Peaks", literaturę grozy, weird ficition, fantastykę, promocję książek, dyskusję na profilu autora powieści „Upał” - Marcina Ciszewskiego, „Harry'ego Pottera”, ,Igrzyska Śmierci”, itd.

Innym miejscem, w którym respondenci wymieniają się opiniami na temat książek, są fora internetowe. Pojawiały się tu zarówno informacje o forach związanych z czytelnictwem, jak i tematycznych, np. forum dla kobiet, o survivalu, o polecanych książkach, itp.

Warto również podkreślić, że pojawiały się komentarze wskazujące na zaangażowanie, ale bez konkretnych informacji, jak: „Tysiące razy. Nie mogę podać jednego przykładu. Nigdy natomiast na Facebooku“, „nie pamiętam", "dużo razy", „wiele takich było" itd.

Co ciekawe, wśród odpowiedzi osób, które brały udział w wymianie zdań o książkach, tylko jeden z respondentów wymienił klub książki online: „Internetowy klub książki Czytają. Dyskusja była prowadzona w komentarzach pod Podcastem".

Pytanie ostatnie brzmiało: "Czy jest Pan/i zainteresowany/a braniem udziału w tego typu dyskusjach online?" Odpowiedzi twierdzącej udzieliły 423 osoby, co stanowi 42,3\% ogółu. Ciekawe w tym miejscu wydaje 
się zestawienie wykresów: obrazującego rozkład odpowiedzi na ww. pytanie oraz wykresu pokazującego reakcję na stwierdzenie „Lubię czytać książki".

Mimo, że ze stwierdzeniem „Lubię czytać książki” zgodziła się większość respondentów - 96,7\%, to zaledwie niecała połowa ma ochotę dzielić się swoimi przemyśleniami, opiniami, odczuciami itd.

Pojawia się więc pytanie, czy autorka badania wywnioskowała słusznie, że osoby czytające chętne są do opowiadania w jakiś sposób o swoich doświadczeniach czytelniczych? Założenie to powstało na podstawie liczby odpowiedzi, szybkości ich udzielania, entuzjastycznej reakcji na ankietę i irytacji, gdy kwestionariusz został zamknięty. Warto zwrócić jednak uwagę, że badanie to było w pełni anonimowe, natomiast aktywność na Facebooku taka zazwyczaj nie jest. Być może więc czytelnicy bardziej skłonni są dzielić się przemyśleniami, nie podpisując się przy tym swoim nazwiskiem?

Z drugiej strony 42,3\% osób zainteresowanych dyskusjami online o książkach nie jest wskaźnikiem niskim. Prawdopodobnie są to osoby aktywne w Internecie, które lubią komentować i wyrażać swoje opinie na różne tematy. Grupa ponad 50\% respondentów, która lubi czytać książ$\mathrm{ki}$, ale nie bierze udziału $\mathrm{w}$ dyskusjach online, prawdopodobnie nie ma potrzeby i nawyku, aby dzielić się opiniami w Internecie. Dla niektórych, problemem może być również korzystanie z sieci.

\section{WNIOSKI}

Artykuł powstał w celu przedstawienia analizy wyników badania ankietowego sprawdzającego poziom wiedzy członków polskich grup czytelniczych na Facebooku na temat zjawiska czytania społecznościowego. Ponadto podjęto próbę ustalenia, czy i jeśli tak, to ile osób brało w nim udział. Respondentów pytano również o to, czy są takim udziałem zainteresowani.

$\mathrm{Z}$ analizy odpowiedzi respondentów wynika, że mniej niż połowa $\mathrm{z}$ nich, rozumie (albo przynajmniej tak twierdzi) pojęcie social reading. $34,8 \%$ odpowiadających przyznało się do udziału w jakiejś formie dyskusji online na temat książki. Jako miejsce tego typu rozmów, respondenci wymieniają: fora internetowe, grupy na Facebooku, sekcję komentarzy pod postami dotyczaccymi danej publikacji, pisarza itp., blogi oraz inne portale, jak BiblioNetka, Lubimy Czytać i znacznie rzadziej academia.edu, Instagram czy YouTube. Zaledwie jedna osoba stwierdziła, że brała udział $\mathrm{w}$ rozmowie na temat książek w klubie książki online, w komentarzach pod Podcastem.

Mimo że ze stwierdzeniem „Lubię czytać książki” zgodziła się większość respondentów - 96,7\%, to zaledwie niecała połowa dzieli się swo- 
imi przemyśleniami, opiniami, odczuciami itd. Informacja ta nie do końca zgadza się z opinią Mannelli, która stwierdziła, że „social reading związane jest z prostą ideą: ludzie chcą dzielić się tym, co czytają" (Mannella, 2011). Podobnie jest w przypadku Tod, która uważa, że zjawisko social reading staje się czymś wszechobecnym poprzez Internet i mobilne urządzenia. Autorka, na podstawie przeprowadzonych przez siebie badań stwierdziła również, że "Czytelnicy uwielbiają rozmawiać o książkach, które czytają. Niektórzy dołączają do fizycznie istniejących klubów książki, inni wybierają kluby książki online" (Tod, 2014). Czy określenie „uwielbiają" (autorka użyła w swoim artykule słowa „love”) nie jest jednak stwierdzeniem zbyt mocnym? Wszakże wg badań przeprowadzonych w 2015 r. przez Tod 45\% respondentów przyznało, że używanie przez nich mediów społecznościowych sprawiło, że czytają więcej. (Tod, 2014), a 50\% osób stwierdziło, że social media zmieniły sposób ich czytania. (Tod, 2015). To zaledwie połowa odpowiadających. Biorąc pod uwagę statystyki podane przez Tod $\mathrm{w}$ raporcie, stwierdzić można, że są one porównywalne z danymi uzyskanymi podczas badania stosunku polskich czytelników do czytania społecznościowego. Warto zwrócić uwagę na informację, że wg raportu Tod, to czytelnicy z USA i Australii najbardziej cenią sobie użycie mediów społecznościowych w czytaniu (Tod, 2015).

\section{OGRANICZENIA}

Jeśli chodzi o ograniczenia przeprowadzonego badania, to należy tu wymienić dobór grup z Facebooka. Być może lepszym rozwiązaniem byłoby podzielenie uzyskanych odpowiedzi na dwie części. Pierwszą z nich stanowiłyby ankiety wypełnione przez członków grup związanych z książkami, a drugą - pozostałych. Wyniki z obu części można by wtedy porównać i ocenić, czy osoby należące do grup tematycznie niezwiązanych z książkami wykazują podobny stosunek do czytelnictwa (zwłaszcza społecznościowego), co użytkownicy grup „czytelniczych”.

Innym ograniczeniem może być długość ankiety. Stworzony kwestionariusz składał się z 14 sekcji i w sumie zawierał 34 pytania. Ostatnim z nich była możliwość zostawienia wiadomości, uwag, dodatkowych komentarzy dla autorki badania. Część osób zamieściła tu informację o tym, że ankieta była "strasznie długa". Podobne komentarze pojawiły się również pod postami w poszczególnych grupach. Pytania dotyczące social reading znajdują się w sekcji nr 12. Fakt, że część respondentów była zmęczona i/lub zirytowana długością ankiety, mógł mieć wpływ na jakość udzielonych przez nich odpowiedzi w końcowych częściach kwestionariusza, w tym w sekcji dotyczącej czytania społecznościowego.

Kolejnym ograniczeniem, które dotyczy wszelkich sondaży i ankiet, jest deklaratywność wypowiedzi, czyli odpowiedzi nieszczere, niepłynące 
z przekonania. Czytanie książek jest nadal postrzegane jako coś, co wypada robić i podobnie może być $\mathrm{z}$ udziałem $\mathrm{w}$ dyskusjach dotyczących danych publikacji. Część respondentów w wiadomościach prywatnych lub we wspomnianej już ostatniej sekcji będącej miejscem na dodatkowy komentarz zamieszczała wyjaśnienia: „bardzo dużo pracuję i nie mam czasu czytać”, „czytam tylko książki związane z pracą” lub „nie biorę udziału w wielu dyskusjach dotyczących książek, bo poziom wielu z nich uważam za zbyt niski". Przytoczone wiadomości zdradzają potrzebę niektórych osób „wytłumaczenia się" z udzielonych odpowiedzi. Istnieje więc przypuszczenie, że mimo anonimowości ankiety niektórzy respondenci mogli swoje odpowiedzi „podkoloryzować”, by wypaść lepiej.

Podsumowując warto zastanowić się, czy social reading sprzyja "tradycyjnemu" czytelnictwu, uzupełnia je, a może jest to przyszłość obcowania ze słowem pisanym? Czytanie społecznościowe rozszerza doświadczenie czytelnika. Może rozwijać takie umiejętności, jak pisanie recenzji, rekomendacji, komunikowanie się z innymi przez media społecznościowe czy wyszukiwanie potrzebnych informacji online. Zachęca do nawiązywania kontaktów, rozmyślań nad tekstem i zadawania pytań. Pomaga też lepiej zapamiętać książkę (Kortas, 2017). Ponadto dyskusja, albo przynajmniej czytanie komentarzy innych osób, może prowadzić do wykrystalizowania się zupełnie innych wniosków niż podczas czytania w pojedynkę. Recenzje, komentarze, rozmowy dotyczące danego tekstu stają się jego częścią - wartością dodaną (Howard, 2017).

Maryl podkreśla, że Internet nie tworzy wymienionych zjawisk, ale je ułatwia. Poprzez sieć, niezależnie od różnic geograficznych czy kulturowych, osoby mające podobne poglądy i przemyślenia mogą się spotkać i podjąć dyskusję na temat danego tekstu (Maryl, 2015). W ten sposób, staje się on pretekstem do zawiązania interakcji poszerzających doświadczenia jednostki (Cordón-García, 2013).

\section{BIBLIOGRAFIA}

Cordón-García, Jose-Antonio i in. (2013). Platforms, Applications, Clouds and Tags (Chandos Publishing Social Media Series) [online], [dostęp: 28.12.2017]. Dostępny w WWW: <https:// pl.scribd.com/read/282654970/Social-Reading-Platforms-Applications-Clouds-andTags $>$.

Encyklopedia PWN [online], [dostęp: 17.05.2019]. Dostępny w WWW: <https://encyklopedia.pwn.pl/>.

Howard, Jennifer (2012). With "Social Reading" Books Become Places to Meet [online], [dostęp: 10.03.2018]. Dostępny w WWW: <http://www.chronicle.com/article/Social-ReadingProjects/135908/>.

Kisilowska, Małgorzata; Paul, Magdalena; Zając, Michał (2016). Jak czytaja Polacy? Raport badawczy projektu Zmiany kultury czytelniczej w Polsce w kontekście upowszechnienia 
e-tekstów i urządzeń pozwalających z nich korzystać [online], [dostęp: 29.12.2017]. Dostępny w WWW: <http://centrumcyfrowe.pl/wp-content/uploads/2016/06/Jak-czytają-Polacy-raport-końcowy.pdf>.

Kortas, Weronika (2017). Social Reading w kontekście nowych technologii: historia, rodzaje, projekty. Toruńskie Studia Bibliologiczne, nr 2 (19) [online], [dostęp: 10.03.2018]. Dostępny w WWW: <http://apcz.umk.pl/czasopisma/index.php/TSB/article/view/ TSB.2017.024/14186>.

Kortas, Weronika (2018). „Czytanie społecznościowe: platformy, aplikacje, chmury i tagi” próba analizy. Toruńskie Studia Bibliologiczne, nr 1 (20) [online], [dostęp: 15.05.2019]. Dostępny w WWW: <http://apcz.umk.pl/czasopisma/index.php/TSB/article/view/TSB. 2018.007/15918>.

Mannella, Allison (2011). What is "Social Reading" and why should Libraries care? Wyniki ankiety [online], [dostęp: 28.12.2017]. Dostępny w WWW: <https://tametheweb.co$\mathrm{m} / 2011 / 06 / 14 /$ what-is-social-reading-and-why-should-libraries-care-a-ttw-guest-postby-allison-mennella/>.

Mannella, Allison (2011). Social Reading and Libraries [online], [dostęp: 28.12.2017]. Dostępny w WWW: <http://www.scribd.com/doc/57754227>.

Maryl, Maciej (2015). Życie literackie w sieci: pisarze, instytucje i odbiorcy wobec przemian technologicznych, Warszawa: Instytut Badań Literackich PAN.

Moyer, Steve (2009). What if? Humanities, vol. 30, no. 4 [online],[dostęp: 28.12.2017]. Dostępny w WWW: <https://www.neh.gov/humanities/2009/julyaugust/feature/what-if>.

Paluszkiewicz-Horubała, Lidia, red. (2017) Stan czytelnictwa w Polsce w 2016 roku. [online], [dostęp: 14.05.2018]. Dostępny w WWW: <http://www.bn.org.pl/download/ document/1493378303.pdf $>$.

Shores, Tyler (2011). Writing in books, and Kindle public notes. [online], [dostęp: 15.05.2018]. WWW: <http://www.tylershores.com/2011/02/24/marginalia-books-and-ebooks/>.

Stetkiewicz, Lucyna (2011). Kulturowi wszystkożercy sięaja po ksiażkę..., Toruń: Wydaw. UMK.

The Meaning of Social Reading and Where It's Headed (2011) [online], [dostęp: 14.05.2019]. Dostępny w WWW: <https://frontmatters.com/2011/12/01/the-meaning-of-social-readingand-where-its-headed/>.

Tod, Mary K. (2014). Favourite Reading Oriented Sites. Readres Choice. [online], [dostęp: 28.12.2017]. Dostępny w WWW: <https://awriterofhistory.com/2014/02/17/favouritereading-oriented-sites-readers-choice/>.

Tod, Mary K. (2014). Social media \& social reading - an author's view. [online], [dostęp: 28.12.2017]. Dostępny w WWW: <http://www.writersworkshop.co.uk/blog/social-media-social-reading-an-authors-view/>.

Tod, Mary K. (2015). 2015 Historical Fiction Reader Survey. [online], [dostęp: 29.04. 2018]. Dostępny w WWW: <https://awriterofhistory.files.wordpress.com/ 2015/06/2015-report-final2.pdf $>$.

Tod, Mary K. (2015). A Writer Of History: Wyniki ankiety "Readres Survey”. [online], [dostęp: 28.12.2017]. Dostępny w WWW: <https://awriterofhistory.com/reader-surveys/2015-reader-survey/>.

What is a book club? [online], [dostęp: 29.12.2017]. Dostępny w WWW: <http://www.bookclubs-resource.com/book-club.php>. 
WERONIKA KORTAS

Nicolaus Copernicus University

e-mail: wkortas@doktorant.umk.pl

\section{MEMBERS OF POLISH FACEBOOK GROUPS AND THE PHENOMENON OF SOCIAL READING ${ }^{1}$}

KEYWORDS: Social reading. Readership. Facebook. Facebook groups. Books.

ABSTRACT: Thesis/Objective - Social reading is a phenomenon of involving large groups of people in reading various texts. Quite naturally, this type of activity is supported by technology. The aim of the article is to analyze the results of a survey intended to check if the members of selected Polish Facebook groups know what social reading is, whether they have taken part in it - consciously or not - and whether they are interested in it. Research method - Groups were selected randomly from those with a minimum of 5,000 members and at least 500 posts published in the last 30 days. As for the subject matter, groups closely related to a specific topic were excluded. As a result of the selection, members of the following groups were invited to complete the survey: „Kreatywne dziewczyny od Ani" „Wrocław - sorry że nie w temacie”, "Książki - sprzedaż/wymiana książek”, „Nie mam czasu, czytam książki". In total, the survey was answered by 1000 respondents. Results/ conclusions - The analysis of the answers shows that less than half of the respondents understand the concept of social reading, and $34.8 \%$ of people admitted they participated in some form of on-line discussion about the book, e.g. at an online message board, in the Facebook group, in the comments section under posts on a given publication, etc. Books read in a social way show that they do not have to be just static texts. Online publications can become meeting places where discussions take place and people share their ideas.

\footnotetext{
${ }^{1}$ This research was financed with WNH UMK grant no 1137-NH (Analyzing methods of using Facebook to promote reading habits).
} 